\title{
Did Plate Tectonics Start with a Bang?
}

\author{
David M. Moerdyk
}

\begin{abstract}
Is it coincidence that two of the largest outpourings of lava in Earth's history, the Deccan Traps and Siberian Traps, occurred simultaneously with the Cretaceous-Tertiary (KT) and Permian-Triassic (PT) extinctions respectively? Either the outpourings of lava caused the extinctions or what caused the extinctions caused the lava outpourings. It is proposed that the primary cause of both extinctions is a bolide impact and that the traps are the antipodal outpourings caused by the impacts. Is it coincidence that the Hawaiian Hotspot lies in the middle of the Pacific Basin? The formation of the hotspot must be related to the formation of the basin. It is proposed that a very large bolide impact created both the Hawaiian Hotspot and the Pacific Basin. These propositions infer several corollaries. The Earth first formed a global continental crust. This global crust lasted until a bolide impact destroyed 2/3 of it to form the Pacific Basin and Hawaiian Hotspot. The impact also caused the PT extinction and the eruption of the Siberian Traps. Subduction plate tectonics did not operate on Earth until the basin crust became negatively buoyant and began to subduct. The KT impact was a smaller version of the PT impact. It broke up crust off the west coast of North America and formed the Yellowstone Hotspot. It also caused the KT extinction and the eruption of the Deccan Traps.
\end{abstract}

Key words: Plate tectonics, hot spot, keel, crustal evolution.

\section{Introduction}

A popular TV investigator likes to say that he does not believe in coincidence. Using the same principle, this paper proposes that it is not a coincidence that the only hot spot not associated with a surface fault (the Hawaiian Hotspot) lies in the middle of the Pacific Ocean. The formation of the hotspot is linked to the formation of the Pacific Basin. It also proposes that it is not a coincidence that the two largest outpourings of molten rock (the Siberian Traps and the Deccan Traps) coincide with the two largest mass extinctions in Earth's history, the PT extinction [1-4] and KT extinction [5] respectively. The outpouring of molten rock was caused by the same event that caused the mass extinctions: large bolide impacts.

Research to find evidence to support these proposals has led to the development of a radical new model of the evolution of the geologic processes on Earth. In this paper the model is referred to as the "global continental

Corresponding author: David M. Moerdyk, independent researcher, research fields: history of the Earth's geologic processes, and modeling flow within the Earth's mantle. crust" model. In brief, the model states that the Earth developed a global continental crust and was evolving to a fixed lid regime like the other terrestrial planets. Then 252 million years ago (Ma) a very large bolide impacted the Earth at a glancing angle. The impact destroyed $2 / 3$ of the Earth's continental crust. The remaining crust is the super continent of Pangea. The destroyed continental crust was replaced by the mafic oceanic crust of the Pacific Basin. After the mafic crust became negatively buoyant, it began to subduct and pulled Pangea apart. This was the start of modern subduction plate tectonics.

This is a radical proposal that requires reanalysis of the evolution of Earth's geology from 4.3 billion years ago (Ga) to $200 \mathrm{Ma}$. An abbreviated analysis is given below. A more extensive analysis can be obtained from the author.

\section{Formation of the Initial Continental Crust, 4.5-2.5 Ga}

The existence of 4.4 Ga zircon crystals [6] indicates that felsic crust existed by $4.4 \mathrm{Ga}[7,8]$. The continuous age distribution of zircons between 3.9 and 
4.3 Ga [9-11] indicates zircons were continuously being generated and, therefore, new continental crust was constantly being formed.

By $4.04 \mathrm{Ga}$, portions of the felsic crust had become rigid enough to survive [12] and form Archean cratons. The increased rigidity of the crust is also indicated by zircon ages being more spaced and clumped around specific ages after $3.9 \mathrm{Ga}$ [9]. Archean cratons are dominated $(80 \%)$ by gneisses of Tonalite-Trondhjemite-Granodiorite composition [13]. The Archean TTG crust is estimated to be $30-40 \mathrm{~km}$ thick $[13,14]$.

Greenstone belts of mafic and ultramafic lavas erupted over the TTG crust [13]. There is no sign of any interaction between the mafic lava and the felsic crust [15]. Therefore, the mafic lava must have risen quickly through the overlying TTG crust in order not to form rocks of intermediate composition.

Lava probably erupted along fissures [16] along the edges of blocks of Archean TTG crust. This produced a matrix of TTG blocks separated by weaker boundaries that later became active eruption and deformation sites. In the eastern Sino-Korean craton, detailed seismic tomography shows an upper mantle made up of vertically and laterally extensive blocks of high-velocity (probably Archean) mantle embedded in a matrix of lower velocity (presumably hot Phanerozoic) mantle [17].

Initially the cooled mafic lava sank into the pliable TTG crust [13]. The sinking of dense greenstone belts into the soft basement indicates that the lithosphere remained hot and soft into the Archean [18, 19].

At the same time that the Archean crust was forming, deep lithospheric "roots" or "keels" were forming beneath the Archean crust [17]. The keels have remained associated with the crust since their formation. The keels have a unique structure of a cool core surrounded by a rigid thermal boundary layer [20]. Seismic readings indicate that the core is cool [21]. The rapid rise of lavas in kimberlite eruptions indicates that the core is composed of low melt temperature material
[22]. The longevity of the keels indicates that the thermal boundary layer is rigid and has a high melt temperature $[23,24]$.

Current models for crustal formation do not produce crust with the above characteristics and/or would not operate at the hotter temperatures that existed before 3.9 Ga. Simulations indicate that subduction plate tectonics would not operate at mantle temperature greater than $275{ }^{\circ} \mathrm{C}$ above current mantle temperature $[25,26]$. Both subduction plate tectonics and delamination propose to generate TTG crust by partial melting of basaltic crust. This requires controlling the melting process to produce less than $20 \%$ melt (less than $1100{ }^{\circ} \mathrm{C}$ ) [27-30]. Controlling the melt temperature and producing $40 \mathrm{~km}$ thick TTG crust with such a low melt percent is unlikely for either process. These models also do not produce a keel with a thermal boundary nor do they explain the bi-modal characteristics of TTG and greenstone belts.

\subsection{Global Continental Crust Formation}

A better model that fits the geologic record is a global felsic crust formed by differentiation. Initially, the felsic layer would be soft and circulate, constantly forming new crust and destroying or submerging parts of the older crust. As the felsic crust cooled, it became a thermal barrier. Mafic material below the felsic crust would over heat. It then would quickly melt through the overlying felsic layer and erupt onto the surface of the felsic crust. As the mafic material cooled, it became denser than the underlying felsic crust and sank into the crust [31]. As it sank, it differentiated to form more felsic crust. The restite continued to sink and settle to the bottom of the felsic layer. This is similar to the fractional crystallization process proposed for forming modern felsic crust [32]. Much of the restite would re-enter the mantle, but some would solidify to form a thermal barrier around the felsic crust thereby allowing a keel to form beneath the Archean crust. The thermal boundary layer of the keels would prevent mixing of rising lava with the felsic crust. This produced the 
bi-modal nature of the erupting lava. As the Earth continued to cool, the felsic layer became stiff enough that the mafic material only partially sank into it. This formed the greenstone belts and granite batholiths. The end result is a global matrix of felsic terrains separated by mafic borders of varying thicknesses.

Earth would then be the same as other planets. On the Moon, anorthite feldspar (plagioclase) rose to the surface and formed the lunar highland crust [33]. On Mars, the topmost crystalizing layer was likely silica-rich (felsic) and buoyant [34]. The type of crust formed on Earth was different because of different conditions. On Earth, the aluminum enters dense garnet crystals and a deep eclogite-rich layer is the result [35]. This would significantly reduce the amount of aluminum available for creating plagioclase. Higher water content and higher pressure also suppressed plagioclase formation [34].

The distribution of radioactive isotopes and their daughter elements supports early differentiation. More than $30 \%$ of the radioactive isotopes, $\mathrm{U}$, Th, and $\mathrm{K}$, are concentrated in the continental crust [35]. If the continental crust was global, nearly all radioactive isotopes would be in the continental crust [13]. Concentrations of short lived radioactive isotopes indicate that the Earth differentiated within the first 100 million years [36-38].

As the global continental crust cooled it became a thermal boundary layer. The thickness of the crust would vary with mantle temperature to accommodate heat loss [39]. This would continue until the Earth cooled enough to solidify the crust. This would be similar to the hot-orogens model that has been proposed [18].

If the stagnant lid could not dissipate the heat through convection and conduction, magma would break through and create "heat pipes" to carry magma and heat to the surface [35]. While the crust is still pliable, the magma sank back into the felsic crust and differentiated as it sank. This formed a vertical gradient of composition [40]. Studies of the continental crust's composition collectively show that the crust becomes more mafic with depth and the concentration of heat-producing elements drops off rapidly with depth [41]. When the crust became more rigid, the magma only partially sank forming greenstone belts.

\section{Evolution toward Pangea, 2.5 Ga-252 Ma}

Analysis of the geologic record indicates that subduction plate tectonics did not operate until $1 \mathrm{Ga}$ [42] or even as late as $488 \mathrm{Ma}$ [43]. The global continental crust model would extend the initiation date to $252 \mathrm{Ma}$.

By $1 \mathrm{Ga}$, most geologic models have large continental masses moving across the Earth. They temporarily join to form super continents and later disperse. Rodinia formed 1000-800 Ma [44], Gondwana formed 650-500 Ma [45] and Pangea formed 330-250 Ma [46].

A major argument against such models is that the joining of large continental masses did not produce large orogenic belts. Collisions of these continental masses are often described as "joining", "docking", or "oblique collision" [47-49]. The merging along the East Africa Orogen (EAO) from 750 to $620 \mathrm{Ma}$ and the additional merging of Australia and East Antarctica between 570 and $530 \mathrm{Ma}$ are both described as oblique continent-continent collisions [50]. Even the joining of Laurentia and Gondwana did not change the shape of the margins of Laurentia [51]. The global continental crust model attributes the small orogenic zones to minimal movement of adjacent continental blocks.

To achieve the joining and dispersal of super continents, continental blocks would have to change direction. Reversal of motion would require the collapse of a passive margin to form an active subduction zone. No examples of this transformation are known in the Cenozoic era $[52,54]$.

Paleomagnetism data support the limited movement of cratons as proposed by the global continental crust model. Paleomagnetism provides evidence that Laurentia, Baltica, and Kalahari were connected for 
long periods of time in the same relative position as they occupy in Pangea. Paleomagnetic measurements indicate that Laurentia and Baltica from 1265-2445 Ma were linked and adjacent [55]. Superior and Kalahari cratons had the same apparent polar wander lengths from 1880-2220 Ma. This would indicate that Kalahari's motions were linked to Laurentia's motions through a supercontinent even though they were located $\sim 60^{\circ}$ apart [55]. One potential position puts Kalahari in nearly the same relative position to Laurentia as it held in Pangea [56].

The longevity of keels beneath cratons is another indication that there were few large collisions prior to the breakup of Pangea. Many credit keels for the longevity of the cratons because they protect cratons from the circulating mantle. However, the unique structure of the keel makes it vulnerable. A small break in the thermal boundary layer would allow intrusion of the mantle into the keel. It would quickly melt through the interior and erupt as a kimberlite eruption. A major break would allow the melting of the interior of the keel. The thermal expansion would cause the cratons to be more positively buoyant and rise. The Colorado Plateau may be an example of keels breaking. Colorado Plateau xenoliths suggest that at 30-20 Ma the Colorado Plateau had a cool root extending to depths of up to $140 \mathrm{~km}$. Current seismic readings provide little evidence that there is still a strong, deep and intact lithospheric root. This indicates that a large portion of the root has recently been removed [57]. The Archean Wyoming Province also has no seismically discernable root at present. However, the province contains numerous $[12,58]$ kimberlites that contain diamonds.

Even small stresses on keels may produce cracks that would produce small eruptions as kimberlite tubes. All kimberlites are less than $200 \mathrm{Ma}$ [24]. This indicates that prior to $200 \mathrm{Ma}$ cratons did not experience high stress that would have cracked the thermal barrier. Therefore cratons could not have been involved in craton-craton collisions that would have cracked the thermal barrier. This is evidence that cratons did not move much prior to $200 \mathrm{Ma}$.

\section{Bolide Impact 252 Ma}

A major challenge to a global crustal model is that $2 / 3$ of the crust must be destroyed and replaced by oceanic crust. If it is not coincidence that the Hawaiian Hotspot lies in the middle of the Pacific Basin, then the formation of the hotspot and the basin must be caused by the same event. It is proposed that that event was the impact of a very large bolide. The continental mass that remained is commonly called the super continent of Pangea. The destruction of the crust enabled the initiation of subduction plate tectonics and the breakup of Pangea around $200 \mathrm{Ma}$.

The impact should have destroyed continental crust in an elliptical pattern [59] leaving a circular shaped super continent. But the popular configuration for Pangea is penetrated by the Tethys Sea.

Fig. 1 and Fig. 2 show an alternative configuration for Pangea. The alternative configuration was generated by first making 3D models of the currently existing continental landmasses and then translating and rotating them on a 3D sphere to obtain the best fit.

The main difference between the new configuration and the standard configuration is that Greenland is rotated to abut to northern Baltica, shown in Fig. 1, instead

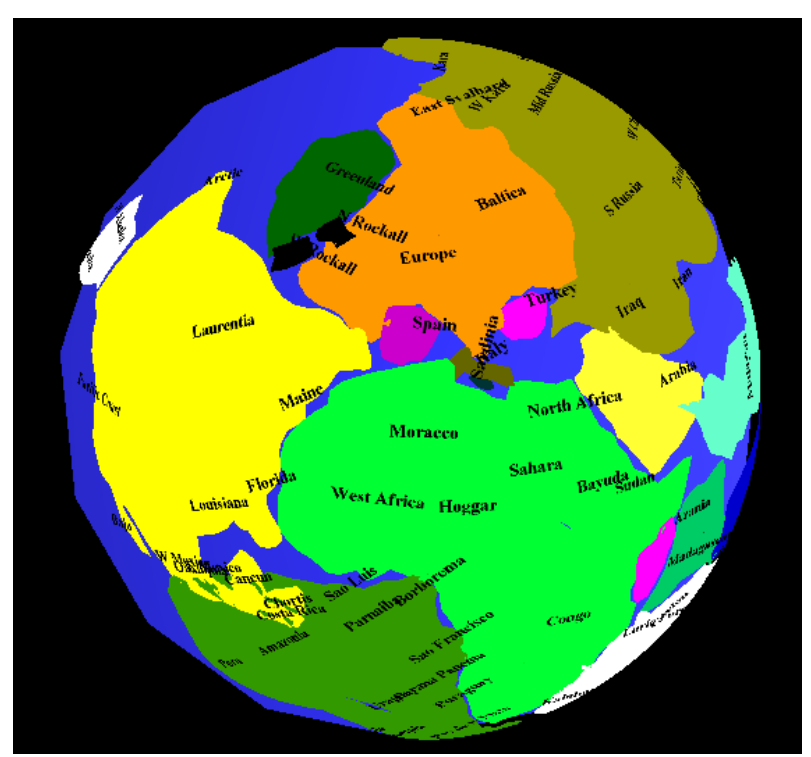

Fig. 1 Rotation of Eurasia. 

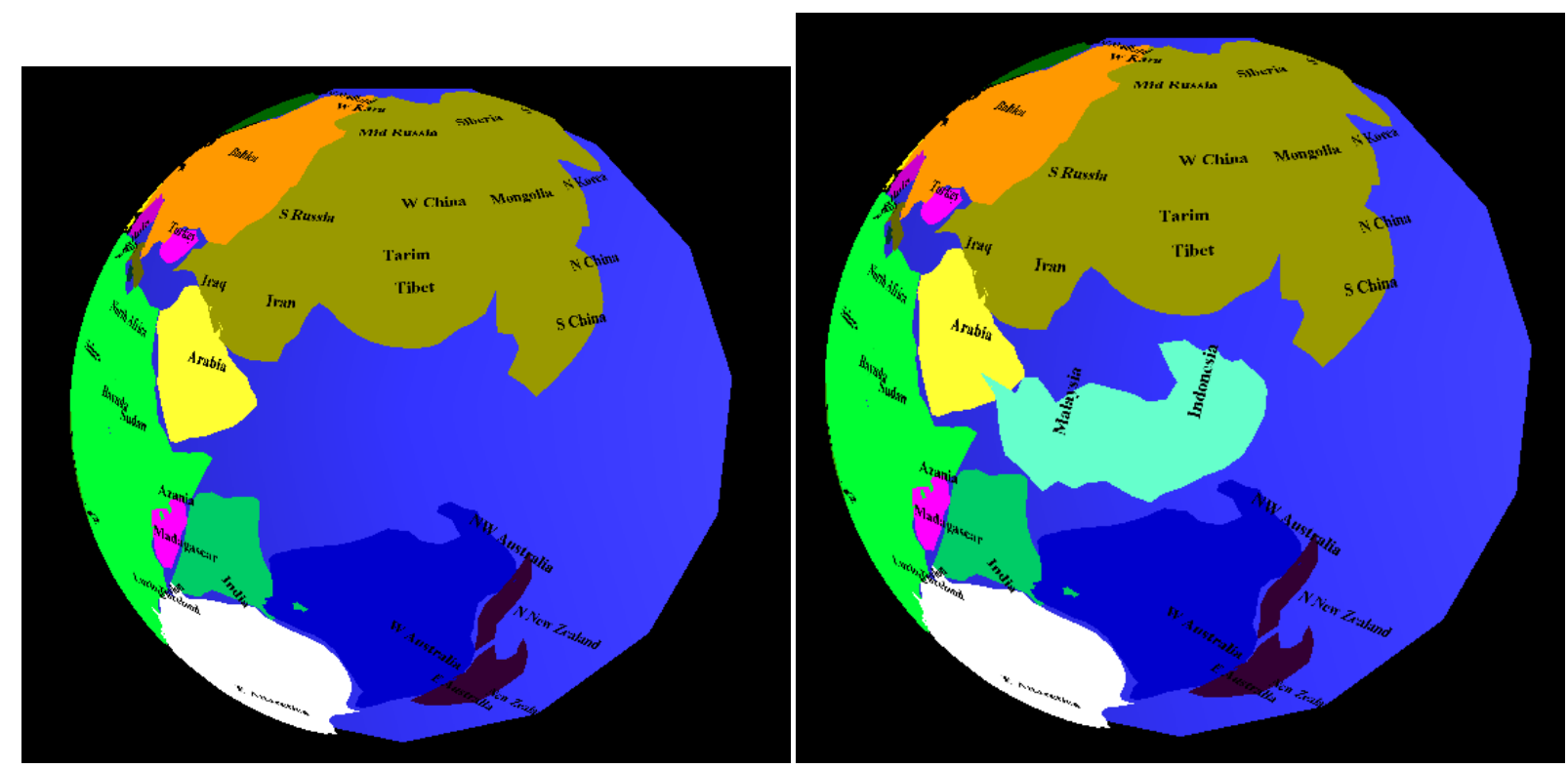

Fig. 2 Filling or the Tethys Sea.

of Baltica rotating to abut to Greenland. The new configuration is justified by deep water trenches between Greenland and Laurentia that indicate that Greenland has been separated from Laurentia. Rotating Greenland instead of Baltica allows the western edge of Baltica to abut the northeast edge of Laurentia. This configuration is justified by bends in the mid-Atlantic ridge that matches the northwest corner of Baltica.

This new configuration reduces the rotation of Baltica and Asia so that the Southern China landmass and the Australia-New Guinea landmass partially enclose the Tethys Sea. This enclosed area is slightly larger than the landmass of Southeast Asia. The area can further be filled in by expanding the Himalaya-Tibet landmass which has contracted from $\sim 500$ to $\sim 1,000 \mathrm{~km}[60]$. The implication is that there was no oceanic crust separating India from Asia. Instead the two landmasses were separated by continental crust which was extruded to become Southeast Asia or contracted into Tibet as India and Asia moved together.

This model agrees with multidisciplinary data which indicate that all the East and SE Asian continental terranes had their origin on the India-N/NW Australian margin [61]. In the early Cenozoic large fragments of
Eurasian lithosphere were extruded eastward out of central Tibet toward southern China and northern Indochina [60].

Earth may not be the only planet with large scale crustal destruction. A bolide impact has been proposed as the cause of Mars' northern hemisphere lowlands [62]. On Venus, $84 \%$ of the craters are in pristine condition and randomly distributed. This strongly indicates that Venus experienced a global resurfacing event between 300 and $500 \mathrm{Ma}$ [63]. A large bolide impact could have caused the resurfacing.

Destruction of $2 / 3$ of the Earth's continental crust would require impact by a very large bolide. The bolide could have been a small planet from within the inner Solar System or it could have come from the outer reaches of the Solar System.

Simulations indicate that the orbits of planets in the Solar System are chaotic. In the future existing planets could leave their current orbits, migrate, and collide with other planets. The instabilities occur over billions of years [64]. This indicates that a planet could have existed in its own orbit for over 4 billion years before becoming unstable and drifting into the gravitational influence of the Earth.

The collision of a wayward planet would be at a 
relatively low velocity, near the escape velocity of the Earth. Loss of momentum from the impact would likely prevent the bolide from escaping Earth's pull and it would go into orbit around the Earth. This would imply that the PT bolide was the Moon. This requires turning the South Pole Aitken (SPA) Basin from one of the oldest geologic features into one of the youngest. This would require that most of the craters within the basin were formed by debris falling back onto the surface after the collision. Many craters in SPA do have young lava flows on their floors as would be expected, in Fig. 3, compared to lunar highland craters, shown in Fig. 4. More investigation into the formation of the
SPA needs to be done before the Moon is a viable option for the PT bolide.

The alternative to an inner Solar System origin of the bolide is an outer Solar System origin. Around 10 dwarf planets with diameters larger than $1,000 \mathrm{~km}$ have been discovered in the Kupier Belt [66]. The inner Oort cloud is estimated to have between 400-1,700 dwarf planets with diameter larger than $1,000 \mathrm{~km}$ [67] . The Earth would not be the first to have a close encounter with large bolides. Various planetary satellites, most small, but at least one substantial (i.e. Triton), were apparently captured from heliocentric orbits [68].

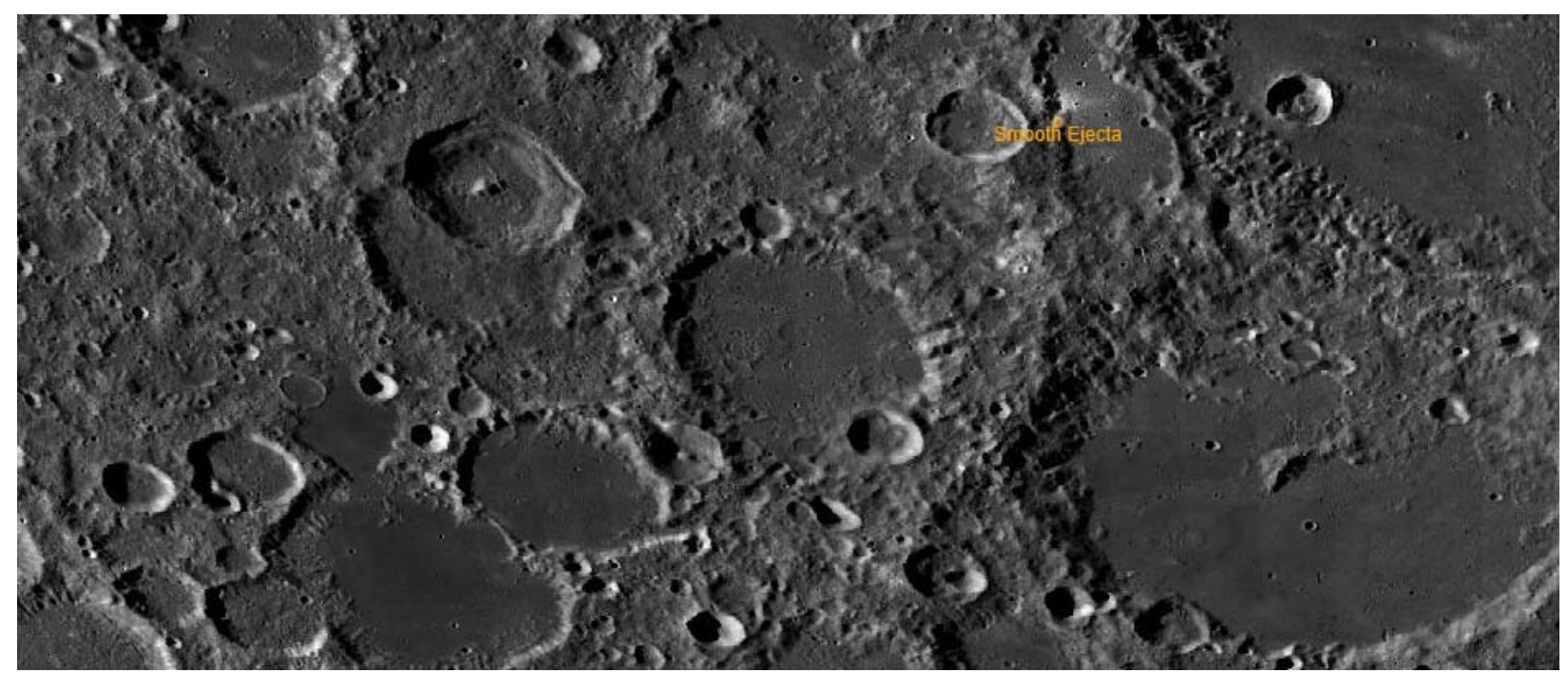

Fig. 3 Craters in South Pole Aitken Basin [65].

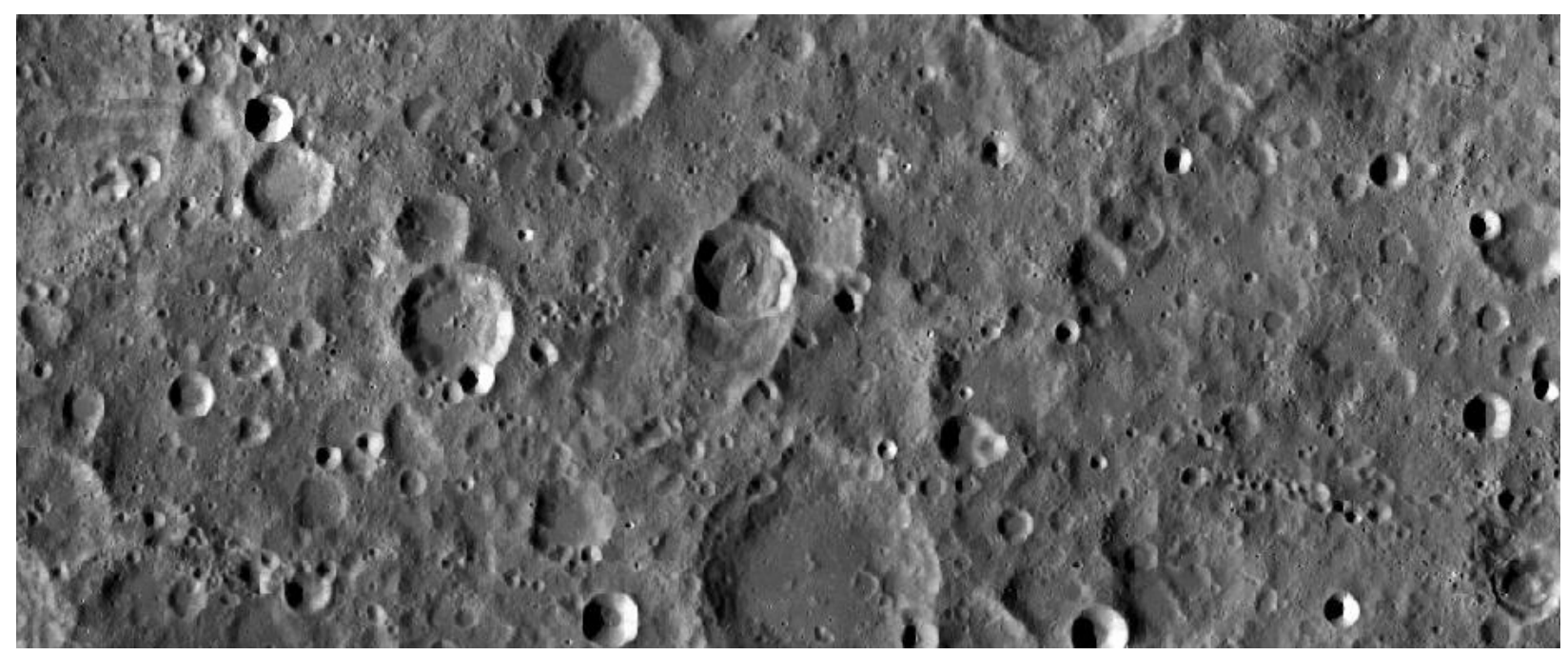

Fig. 4 Lunar Highlands craters [65]. 
The feasibility of a bolide destroying $2 / 3$ of the Earth's crust will require a very detailed and complex simulation. To date, few giant bolide impacts have been simulated. The basin forming impact on Mars has been simulated [69] and the Moon forming impact has been modeled [70]. An impact that would destroy 2/3 of the Earth's continental crust would lie between the sizes of these two. Both of these simulations used a smoothed particle hydrodynamics (SPH) model. The size of an individual particle is about $118 \mathrm{~km}$. The simulation of the destruction of the continental crust must have a resolution about the thickness of the crust, $40 \mathrm{~km}$. A much higher resolution simulation must be developed. Advances in the use of adaptive mesh refinement (AMR) [71] may make such a simulation possible. Until such a simulation can be performed, the geologic record must be explored for evidence of such a large impact.

\subsection{Pacific Basin}

The bolide impact would have instantaneously formed large areas of oceanic crust. This crust should all have the same age and show no magnetic striping. Unfortunately, most of that crust has been destroyed through the process of subduction. Candidate locations for remnants of this crust would be areas between converging continents like the Arctic Ocean or the Pacific Basin.

Portions of the Arctic Ocean Basin do lack magnetic striping. The crustal structure, age, and origin of the main tectonic blocks are not well enough resolved to make definitive conclusions [72]. However, some analyses have concluded that there may be a trapped piece of Jurassic ocean floor within the basin [73]

The Pacific Basin has one possible area for a remnant. The Jurassic Magnetic Quit Zone (JQZ) in the south western Pacific has no or very weak magnetic striping. The JQZ has a unique triangular shape defined by magnetic striping at its boundaries. Plate history models have the JQZ forming at a spreading triple junction that had existed for millions of years before the JQZ was formed [74]. The formation of the JQZ either requires unique events [75] or a remnant of a previous crust.

Drilling projects have determined the age of the surface lava within the JQZ to be $167 \mathrm{Ma}$ [73]. This would indicate that the JQZ formed after the breakup of Pangea unless eruptions continued for millions of years after its initial creation. Drilling shows that magmatism in the JQZ did last for at least 13 million years. The floor is vertically layered. The top layer is dated at 157 Ma. The last layer drilled into is dated at $170 \mathrm{Ma}$ [76]. It is unknown what layers lie below the $170 \mathrm{Ma}$ layer.

The bolide impact could have left partially destroyed continental crust. The Ontong Java Plateau (OJP) in the Western Pacific is the primary candidate for a segment of partially destroyed continental crust.

OJP has several characteristics that indicate it is a sunken piece of continental crust. OJP has a broad and relatively flat surface [77]. High seismic velocities are observed in the lower crust of Ontong Java [77]. The central part of the OJP has seismic characteristics of a continental fragment, differing only in that the Moho is depressed by a thick basal layer [78]. Its crustal thickness of $30 \mathrm{~km}$ matches continental crustal thickness [79]. The OJP and Manihiki plateaus have enough $\mathrm{Cr}$ and $\mathrm{Ni}$ to match average continental crust [80]. Isotopic composition of lavas indicates that up to $30 \%$ is incorporated from ancient lower continental crustal material [81].

The OJP even has a keel. A seismic discontinuity at $283 \mathrm{~km}$ could indicate the base of a keel [82]. A three-dimensional tomographic model indicates the existence of a low-velocity mantle keel reaching the depth of $\sim 300 \mathrm{~km}$ [83]. If such velocities were entirely thermal in origin, then the root would be up to $700{ }^{\circ} \mathrm{C}$ hotter than surrounding mantle, hot enough to cause continuing volcanism [84]. This is different from the keels beneath cratons which have a cool, high velocity mantle keel. The keel below the OJP could have been transformed from a cool keel to a warm keel if the thermal boundary layer at the bottom of the keel was 
significantly cracked to allow hot mantle to enter. It would melt the low melt temperature interior of the keel. The OJP would rise as the density of the keel decreased. As mantle material mixed into the keel, the buoyancy of the OJP would decrease and it would start to sink. The thermal boundary layer on the sides of the keel would then prevent the interior of the keel from cooling.

Like the JQZ, the OJP has young lava on its surface. Measured ages range between 88 and $125 \mathrm{Ma}$ [85]. This too could be caused by ongoing eruptions as a lack of reversing magnetic isochrones in the surrounding basins [85] may indicate.

The destroyed continental crust would have enriched the lithosphere in incompatible isotopes and changed composition of Ocean Island Basalts (OIBs) that are erupted in the Pacific Basin as compared to other basins. The Western Pacific Seamount Province (WPSP) does exhibit a geochemical composition that spans almost the whole OIB array on an area that covers only $\sim 0.14 \%$ of the Earth's surface. It also exhibits a highly complex and irregular age-distance relationship [86].

\subsection{Timing of the Impact}

The bolide impact enabled the breakup of Pangea. Therefore the impact must have occurred at the time of Pangea breakup at $201 \mathrm{Ma}$ or before it. The Permian-Triassic (PT) extinction is the largest mass extinction in Earth's history [87]. This plus similarities to events at the Cretaceous-Tertiary (KT) boundary make $252 \mathrm{Ma}$ the prime date for the impact.

This means that there was a delay of 51 Ma between the impact and when Pangea started breaking up 201 Ma. The best explanation for this delay is that it took that long for the new oceanic crust to become neutrally buoyant and begin to subduct. Currently, time to neutral buoyancy is about $25 \mathrm{Ma}$ [88]. The time increases by $\sim 50 \mathrm{Ma}$ for an increase of $100 \mathrm{~K}$ in mantle temperature [89]. $252 \mathrm{Ma}$ the mantle temperature was about $50{ }^{\circ} \mathrm{C}$ warmer [90]. This would mean that the time to neutral buoyancy was about 50 Ma which is in good agreement with the delay in breakup.

If a bolide impact caused the P-T extinction, the pattern of extinction should be unique to a bolide impact. The fossil record indicates that the PT extinction was worldwide and occurred in a geologic instant [91-95]. Seawater temperatures increased from $21{ }^{\circ} \mathrm{C}$ to $36{ }^{\circ} \mathrm{C}$ [96]. Analysis of the carbon cycle indicates that the amount of carbon requires an implausibly large source. This indicates that a bolide impact triggered both the release of $\mathrm{CH}_{4}$ from stored hydrates and the initiation of Siberian volcanism [97].

The breakup of Pangea and the initiation of subduction plate tectonics increased the amount of volcanism. There were a sparse number of samples of primary lavas between $2.0 \mathrm{Ga}$ and 252 Mya. The number of samples substantially increases after 252 Mya [26].

The creation of the deep ocean basin, the increase in exposed land, and the increase in elevation difference produced a wider range of ecosystems and an increase in the diversity of species. The number of genera increased dramatically during the Ordovician (500-450 Ma). Then the number of genera stayed around 1,000 until the PT extinction. Since the PT extinction the number of genera has steadily increased to a present number of over 5,000 [98].

\subsection{KT-PT Similarities}

It is proposed that the PT bolide impact is a larger version of the KT bolide impact. Both the PT and KT impacts formed hotspots, the Hawaiian and Yellowstone Hotspots respectively. The Chicxulub Crater is therefore a secondary impact at the KT boundary. Both caused antipodal outpourings, the Siberian and Deccan Traps respectively. The impacts differ in that the PT bolide impacted at a glancing angle while the KT bolide impacted at a near vertical angle.

The location of the Hawaiian Hotspot indicates that it was formed by the PT bolide impact that formed the Pacific Basin. If the KT bolide impact is a smaller 
version of the PT impact, it likely also formed a hotspot. The Yellowstone Hotspot is the most similar hotspot to the Hawaiian Hotspot and therefore the prime candidate.

The hotspots would initially be formed when the bolide impact compresses and melts a column of mantle beneath the impact point. Molten mantle begins to rise. The rising flow could be maintained by an exothermic phase transformation at the $660 \mathrm{~km}$ depth discontinuity. Various minerals transition their structure as they transit through about $660 \mathrm{~km}$ depth [99]. This transformation has a negative Clapeyron slope [100]. Ascending material undergoes an exothermic (releasing heat) reaction [99] that could heat the rising magma and assist the upwelling.

Seismic imaging of the mantle beneath the Hawaiian and Yellowstone hotspots, in Fig. 5, supports this model by showing a transition in the structure of the upwelling at the $660 \mathrm{~km}$ depth [101-103]. A narrow conduit rises from the $660 \mathrm{~km}$ discontinuity. Below the $660 \mathrm{~km}$ discontinuity a circular area of hot material

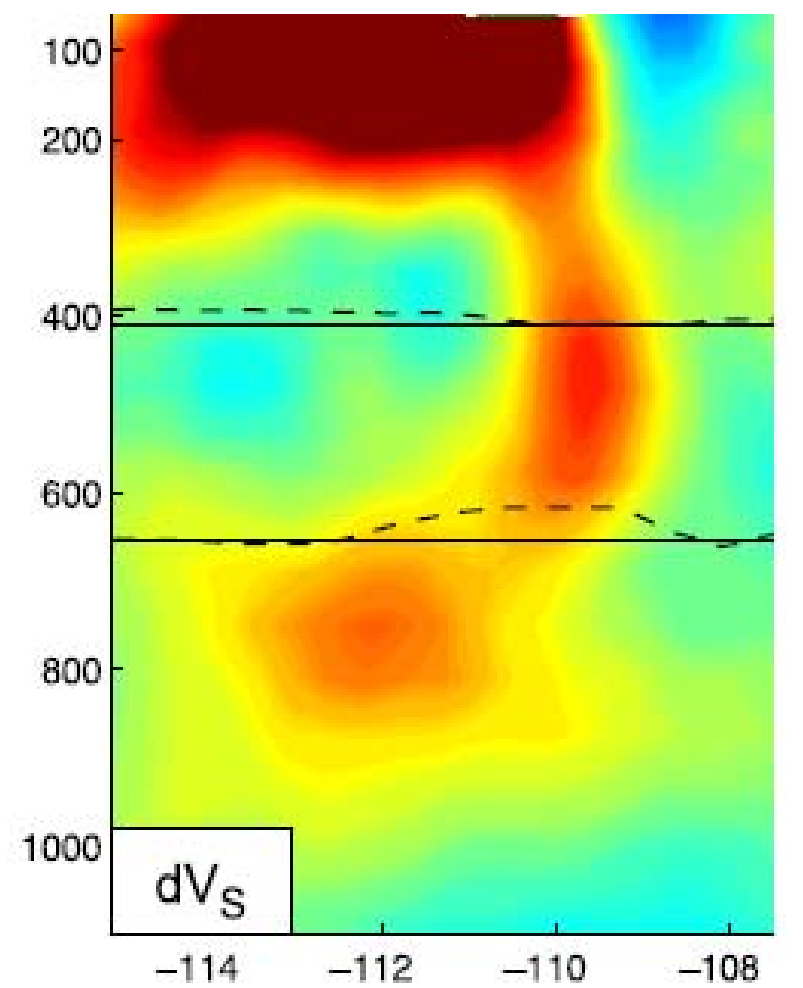

Fig. 5 Seismic imagery of the Yellowstone Hotspot (B. Schmandt, EPSL May 2012). exists down to $1,000 \mathrm{~km}$. The circular structure of the heated material below the $660 \mathrm{~km}$ depth indicates that material is being sucked up through the $660 \mathrm{~km}$ discontinuity and not pushed from below.

There is some direct evidence that the Yellowstone Hotspot was formed coeval with the KT impact at 65 Ma. $65 \mathrm{Ma}$ the location of Yellowstone Hotspot would have been well off the west coast of North America. Therefore, the KT bolide would have impacted the Earth off the west coast of North America and should have altered the coast line. Age of basement rocks systematically decrease from $62 \mathrm{Ma}$ around the Oregon/California boarder and $57 \mathrm{Ma}$ around Vancouver Island to $49 \mathrm{Ma}$ at the Columbia Gorge. This has been interpreted as evidence of volcanic chains generated by the Yellowstone Hotspot, which were accreted to form the Coast Range terrane [104]. Volcanic activity extends to the Aleutian Islands with dates between $61 \mathrm{Ma}$ and $26 \mathrm{Ma}$ [105]. The maximum age of $62 \mathrm{Ma}$ for intrusions is coincidentally close to the 65 Ma date of the KT impact.

A rise of magma would have formed beneath a thin crust. As the hotspot came onshore, the thin crust would have ruptured and released the magma that had accumulated. The large outpouring could have formed the Columbian Basin basalt fields. This model is supported by the composition of magmas away from the hotspot track along the Columbia River and Steens Mountain which indicates they had stagnated at shallow depth where they differentiated [106].

A low velocity anomaly extends in a straight line from the Yellowstone hotspot back to approximately San Francisco California [107]. The Yellowstone Hotspot could have formed this anomaly as the North American plate moved west-southwest over it.

The coeval occurrence of the PT extinction event and the formation of the Siberian Traps [1-4] and the coeval occurrence of the KT extinction event and the formation of the Deccan Traps [5, 108] are probably not a coincidence. It is more likely that the impacts caused the large igneous provinces. The traps would 
therefore be the antipodal outpourings caused by the impacts. The rapid extrusion of lava, in less than 1 million years [2] would be expected for an antipodal eruption. This is a stronger cause-and-effect than the proposal that the seismic waves from an impact increased the outflow of the Deccan Traps eruption $[109,110]$.

If the KT bolide impact caused the formation of the Deccan Traps at its antipodal location, then the relative location of the Yellowstone Hotspot to the Deccan Traps location at $65 \mathrm{Ma}$ should be correlated. The Deccan Traps are currently located on the India landmass at about $20^{\circ} \mathrm{N}$ and $74^{\circ} \mathrm{E}$. India has been moving north at approximately 9 meters per century [111]. Assuming the same velocity over the last $65 \mathrm{Myr}$, India would be $5,850 \mathrm{~km}$, or 52 degrees, farther south. This would place the Deccan Traps at approximately $32^{\circ} \mathrm{S}$ and $70^{\circ} \mathrm{E}$ at the time of impact. The Yellowstone Hotspot is at $44^{\circ} \mathrm{N}$ and $110^{\circ} \mathrm{W}$. The antipodal point would therefore be approximately $168^{\circ}$ away from the impact point, indicating a near vertical hit.

It is more difficult to determine the location of the Siberian Traps 252 Ma. If the destruction of the continental crust was symmetrical around the impact point, then a vertical impact should have produced an antipodal point in the middle of Pangea. Instead, the Siberian Traps lie near the edge of Pangea. This would be expected for a low impact angle.

For a low impact, most of the bolide would escape the Earth. It would not leave an iridium spike at the PT boundary [112]. The bolide impact would have produced high temperature structures such as fullerenes [112, 113] and Fe-Si-Ni grains [114].

\section{Conclusion}

At a minimum this paper has shown that geologic processes change with time. It has also made a case for a radical new model of the evolution of the Earth, a model that proposes that subduction plate tectonics did not start until after the big bang of a bolide impact created oceanic crust that would subduct after cooling.
Proper evaluation of the model will require an open mind and more precise definition and analysis of the geologic record. It will take a more global view, not limited to a few rock samples or to a limited field of study. The geologic record is complex and is easier to analyze if filters are applied. Yet every rock has a history that must fit into the evolution of the Earth.

\section{References}

[1] Reichow, M. K., Pringil, M. S., AL'Mukhamedov, A. I., Allen, M. B., Andreichev, V. L., Buslov, M. M., et al, 2009. "The Timing and Extent of the Eruption of the Siberian Traps Large Igneous Province: Implications for the End-Permian Environmental Crisis.” Earth Planet. Sci. Lett. 277 (1-2): 9-20.

[2] Kamo, S. L., Czamanske, G. K., Amelin, Y., Fedorenko, V. A., Davis, D., and Trofimov, V. 2003. "Rapid Eruption of Siberian Flood-Volcanic Rocks and Evidence for Coincidence with the Permian-Triassic Boundary and Mass Extinction at 251 Ma." Earth Planet. Sci. Lett. 214 (1-2): 75-91.

[3] Courtillot, V. E., and Renne, P. R. 2003. "On the Ages of Flood Basalt Events.” Comptes Rendus Geosci. 335 (1): $113-40$

[4] Bowring, S. A. 1998. "U/Pb Zircon Geochronology and Tempo of the End-Permian Mass Extinction." Science 280 (5366): 1039-45.

[5] Chenet, A., Quidelleur, X., Fluteau, F., Courtillot, V., and Bajpai, S. 2007. "40K-40Ar Dating of the Main Deccan Large Igneous Province: Further Evidence of KTB Age and Short Duration.” Earth Planet. Sci. Lett. 263 (1-2): 1-15.

[6] Peck, W. H., Valley, J. W., Wilde, S. A., and Graham, C. M. 2001. "Oxygen Isotope Ratios and Rare Earth Elements in 3.3 to $4.4 \mathrm{Ga}$ Zircons: Ion Microprobe Evidence for High $\delta 18$ O Continental Crust and Oceans in the Early Archean." Geochim. Cosmochim. Acta 65 (22): 4215-29.

[7] Froude, D. O., Ireland, T. R., Kinny, P. D., Williams, I. S., Compston, W., Williams, I. R., et al. 1983. "Ion Microprobe Identification of 4,100-4,200 Myr-Old Terrestrial Zircons.” Nature 304 (5927): 616-8.

[8] O'Neil, J., Carlson, R. W., Francis, D., and Stevenson, R. K. 2008. "Neodymium-142 Evidence for Hadean Mafic Crust." Science 321 (5897): 1828-31.

[9] Kemp, A. I. S., Wilde, S. A., Hawkesworth, C. J., Coath, C. D., Nemchin, A., Pidgeon, R. T., et al. 2010. "Hadean Crustal Evolution Revisited: New Constraints from $\mathrm{Pb}-\mathrm{Hf}$ Isotope Systematics of the Jack Hills Zircons." Earth Planet. Sci. Lett. 296 (1-2): 45-56. 
[10] Harrison, T. M. 2005. "Heterogeneous Hadean Hafnium: Evidence of Continental Crust at 4.4 to 4.5 Ga." Science 310 (5756): 1947-50.

[11] Næraa, T., Scherstén, A., Rosing, M. T., Kemp, A. I., Hoffmann, J. E., Kokfelt, T. F., et al. 2012. "Hafnium Isotope Evidence for a Transition in the Dynamics of Continental Growth 3.2 Gyr Ago." Nature 485 (7400): 627-30.

[12] Griffin, W. L., O'Reilly, S. Y., Doyle, B. J., Pearson, N. J., Coopersmith, H., Kivi, K., et al. 2004. "Lithosphere Mapping beneath the North American Plate 2$\}$." Lithos 77 (1-4): 873-922.

[13] Hamilton, W. B. 2007. "Earth's First Two Billion Years-The Era of Internally Mobile Crust." In Geological Society of America Memoirs, vol. 200, Geological Society of America, pp. 233-96.

[14] Bédard, J. H., Harris, L. B., and Thurston, P. C. 2013. "The hunting of the snArc." Precambrian Res. 229: 20-48.

[15] Arndt, N. 1999. "Why Was Flood Volcanism on Submerged Continental Platforms So Common in the Precambrian?" Precambrian Res. 97 (3): 155-64.

[16] Arndt, N., and Lesher, C. M. 2004. "Komatiite." Encycl. Geol., pp. 298-311.

[17] O’Reilly, S. Y., Griffin, W. L., Poudjom Djomani, Y. H., and Morgan, P. 2001. "Are Lithospheres Forever? Tracking Changes in Subcontinental Lithospheric Mantle Through Time." GSA Today 11 (4): 4.

[18] Van Hunen, J., and Moyen, J.-F. 2012. "Archean Subduction: Fact or Fiction?” Annu. Rev. Earth Planet. Sci. 40 (1): 195-219.

[19] Choukroune, P., Bouhallier, H., and Arndt, N. T. 1995. "Soft Lithosphere during Periods of Archaean Crustal Growth or Crustal Reworking." Geol. Soc. Lond. Spec. Publ. 95 (1): 67-86.

[20] King, S. 2005. "Archean Cratons and Mantle Dynamics." Earth Planet. Sci. Lett. 234 (1-2): 1-14.

[21] Goes, S., and van der Lee, S. 2002. "Thermal Structure of the North American Uppermost Mantle Inferred from Seismic Tomography." J. Geophys. Res. Solid Earth 107 (B3): ETG-1-ETG 2-13.

[22] Haggerty, S. E. 1999. "A Diamond Trilogy: Superplumes, Supercontinents, and Supernovae." Science 285 (5429): 851-60.

[23] Sleep, N. H. 2005. "Evolution of the Continental Lithosphere." Annu. Rev. Earth Planet. Sci. 33 (1): 369-93.

[24] Mitchell, R. H. 1991. "Kimberlites and Lamproites: Primary Sources of Diamond." Geosci. Can. 18 (1): 1-16.

[25] Sizova, E., Gerya, T., Brown, M., and Perchuk, L. L. 2010. "Subduction Styles in the Precambrian: Insight from Numerical Experiments." Lithos 116 (3-4): 209-29.

[26] Van Hunen, J., van Keken, P. E., Hynes, A., and Davies, G.
F. 2008. "Tectonics of Early Earth: Some Geodynamic Considerations." In Special Paper 440: When Did Plate Tectonics Begin on Planet Earth? Vol. 440, Geological Society of America, pp. 157-71.

[27] Rapp, R. P., Watson, E. B., and Miller, C. F. 1991. "Partial Melting of Amphibolite/Eclogite and the Origin of Archean Trondhjemites and Tonalites." Precambrian Res. 51 (1-4): 1-25.

[28] Hirose, K., and Kushiro, I. 1993. "Partial Melting of Dry Peridotites at High Pressures: Determination of Compositions of Melts Segregated from Peridotite Using Aggregates of Diamond.” Earth Planet. Sci. Lett. 114 (4): 477-89.

[29] Klemme, S., Blundy, J. D., and Wood, B. J. 2002. "Experimental Constraints on Major and Trace Element Partitioning during Partial Melting of Eclogite." Geochim. Cosmochim. Acta 66 (17): 3109-23.

[30] Zhang, C., Holtz, F., Koepke, J., Wolff, P. E., Ma, C., and Bédard, J. H. 2013. "Constraints from Experimental Melting of Amphibolite on the Depth of Formation of Garnet-Rich Restites, and Implications for Models of Early Archean Crustal Growth." Precambrian Res. 231: 206-17.

[31] Hamilton, W. B. 2003. “An Alternative Earth.” GSA Today 13 (11): 4-12.

[32] Keller, C. B., Schoene, B., Barboni, M., Samperton, K. M., and Husson, J. M. 2015. "Volcanic-Plutonic Parity and the Differentiation of the Continental Crust." Nature 523 (7560): 301-7.

[33] Elkins-Tanton, L. T., Burgess, S., and Yin, Q.-Z. 2011. "The Lunar Magma Ocean: Reconciling the Solidification Process with Lunar Petrology and Geochronology." Earth Planet. Sci. Lett. 304 (3-4): 326-36.

[34] Elkins-Tanton, L. T. 2005. "Possible Formation of Ancient Crust on Mars through Magma Ocean Processes." J. Geophys. Res. 110 (12): 1-11.

[35] Anderson, D. L., and Anderson, D. L. 2007. New Theory of the Earth. Cambridge, New York: Cambridge University Press.

[36] Allègre, C. J., Staudacher, T., Sarda, P., and Kurz, M. 1983. "Constraints on Evolution of Earth's Mantle from Rare Gas Systematics.” Nature 303: 762-6.

[37] Bennett, V. C., Brandon, A. D., and Nutman, A. P. 2007. "Coupled 142Nd-143Nd Isotopic Evidence for Hadean Mantle Dynamics.” Science 318 (5858): 1907-10.

[38] Jacobsen, S. B. 2003. "Geochemistry: How Old Is Planet Earth?” Science 300 (5625): 1513-4.

[39] Stern, R. J. 2007. "When and How Did Plate Tectonics Begin? Theoretical and Empirical Considerations." Chin. Sci. Bull. 52 (5): 578-91.

[40] Davies, G. F. 2002. "Stirring Geochemistry in Mantle Convection Models with Stiff Plates and Slabs." Geochim. 
Cosmochim. Acta 66 (17): 3125-42.

[41] Rudnick, R. L., and Gao, S. X. 2003. "Composition of the Continental Crust." Treatise Geochem. 3: 1-64.

[42] Stern, R. J. 2005. "Evidence from Ophiolites, Blueschists, and Ultrahigh-Pressure Metamorphic Terranes That the Modern Episode of Subduction Tectonics Began in Neoproterozoic Time." Geology 33 (7): 557.

[43] Hamilton, W. B. 2011. "Plate Tectonics Began in Neoproterozoic Time, and Plumes from Deep Mantle Have Never Operated." Lithos 123 (1-4): 1-20.

[44] Li, Z. X., Bogdanova, S. V., Collins, A. S., Davidson, A., Waele, B. D., Ernst, R. E., et al. 2008. "Assembly, Configuration, and Break-Up History of Rodinia: A Synthesis." Precambrian Res. 160 (1-2): 179-210.

[45] Meert, J. G., and Lieberman, B. S. 2008. "The Neoproterozoic Assembly of Gondwana and Its Relationship to the Ediacaran-Cambrian Radiation." Gondwana Res. 14 (1-2): 5-21.

[46] Torsvik, T. H. 2003. "Geology: Enhanced: The Rodinia Jigsaw Puzzle.” Science 300 (5624): 1379-81.

[47] Bogdanova, S. V., Bingen, B., Gorbatschev, R., Kheraskova, T. N., Kozlov, V. I., Puchkov, V. N., et al. 2008. "The East European Craton (Baltica) before and during the Assembly of Rodinia." Precambrian Res. 160 (1-2): 23-45.

[48] Meert, J. G. 2003. "A Synopsis of Events Related to the Assembly of Eastern Gondwana." Tectonophysics 362 (1): $1-40$.

[49] Veevers, J. J. 2004. "Gondwanaland from 650-500 Ma Assembly through 320 Ma Merger in Pangea to 185-100 Ma Breakup: Supercontinental Tectonics via Stratigraphy and Radiometric Dating." Earth-Sci. Rev. 68 (1-2): 1-132.

[50] Thomas, W. A. 2006. "Tectonic Inheritance at a Continental Margin." GSA Today 16 (2): 4-11.

[51] Mueller, S., and Phillips, R. J. 1991. "On the Initiation of Subduction.” J. Geophys. Res. Solid Earth 96 (B1): 651-65.

[52] Stern, R. J. 2004. "Subduction Initiation: Spontaneous and Induced." Earth Planet. Sci. Lett. 226 (3-4): 275-92.

[53] Silver, P. G., and Behn, M. D. 2008. "Intermittent Plate Tectonics?" Science 319 (5859): 85-8.

[54] Evans, D. A. D., and Pisarevsky, S. A. 2008. "Plate Tectonics on Early Earth? Weighing the Paleomagnetic Evidence." In Special Paper 440: When Did Plate Tectonics Begin on Planet Earth? Vol. 440, Geological Society of America, pp. 249-63.

[55] Hanson, R. E., Crowley, J. L., Bowring, S. A., Ramezani, J., Gose, W. A., Pancake, J. A., et al. 2004. "Coeval Large-Scale Magmatism in the Kalahari and Laurentian Cratons During Rodinia Assembly." Science 304 (5674): 1126-9.

[56] Obrebski, M., Allen, R. M., Pollitz, F., and Hung, S.-H.
2011. "Lithosphere-Asthenosphere Interaction beneath the Western United States from the Joint Inversion of Body-Wave Traveltimes and Surface-Wave Phase Velocities: Multi-phase Tomography of the Western US." Geophys. J. Int. 185 (2): 1003-21.

[57] O’Neill, C. J., Lenardic, A., Griffin, W. L., and O'Reilly, S. Y. 2008. "Dynamics of Cratons in an Evolving Mantle." Lithos 102 (1-2): 12-24.

[58] Andrews-Hanna, J. C., Zuber, M. T., and Banerdt, W. B. 2008. "The Borealis Basin and the Origin of the Martian Crustal Dichotomy." Nature 453 (7199): 1212-5.

[59] Royden, L. H., Burchfiel, B. C., and van der Hilst, R. D. 2008. "The Geological Evolution of the Tibetan Plateau." Science 321 (5892): 1054-8.

[60] Metcalfe, I. 1998. "Palaeozoic and Mesozoic Geological Evolution of the SE Asian Region: Multidisciplinary Constraints and Implications for Biogeography." Biogeogr. Geol. Evol. SE Asia, pp. 25-41.

[61] Wilhelms, D. E., and Squyres, S. W. 1984. "The Martian Hemispheric Dichotomy May Be due to a Giant Impact." Nature 309 (5964): 138-40.

[62] Strom, R. G., Schaber, G. G., and Dawson, D. D. 1994. "The Global Resurfacing of Venus." J. Geophys. Res. Planets 99 (E5): 10899-926.

[63] Laskar, J., and Gastineau, M. 2009. "Existence of Collisional Trajectories of Mercury, Mars and Venus with the Earth." Nature 459 (7248): 817-9.

[64] "QuickMap: NASA/GSFC/Arizona State University." [Online]. Available: http://target.lroc.asu.edu/q3/ (Accessed: 04-Aug-2016).

[65] Brown, M. E. 2008. "The Largest Kuiper Belt Objects." Sol. Syst. Neptune 639 (1): L43-6.

[66] Trujillo, C. A., and Sheppard, S. S. 2014. "A Sedna-Like Body with a Perihelion of 80 Astronomical Units." Nature 507 (7493): 471-4.

[67] Stern, S. A., and Levison, H. F. 2000. "Regarding the Criteria for Planethood And Proposed Planetary Classification Schemes." Highlights Astron. 12: 205-13.

[68] Marinova, M. M., Aharonson, O., and Asphaug, E. 2011. "Geophysical Consequences of Planetary-Scale Impacts into a Mars-Like Planet.” Icarus 211 (2): 960-85.

[69] Canup, R. M. 2004. "Origin of the Terrestrial Planets and the Earth-Moon System.” Phys. Today 57 (4): 56-62.

[70] Stadler, G., Gurnis, M., Burstedde, C., Wilcox, L. C., Alisic, L., and Ghattas, O. 2010. "The Dynamics of Plate Tectonics and Mantle Flow: From Local to Global Scales." Science 329 (5995): 1033-8.

[71] Alvey, A., Gaina, C., Kusznir, N. J., and Torsvik, T. H. 2008. "Integrated Crustal Thickness Mapping and Plate Reconstructions for the High Arctic." Earth Planet. Sci. Lett. 274 (3-4): 310-21.

[72] Seton, M., Müller, R. D., Zahirovic, S., Gaina, C., Torsvik, 
T., Shephard, G., et al. 2012. "Global Continental and Ocean Basin Reconstructions since 200Ma." Earth-Sci. Rev. 113 (3-4): 212-70.

[73] Coltice, N., Seton, M., Rolf, T., Müller, R. D., and Tackley, P. J. 2013. "Convergence of Tectonic Reconstructions and Mantle Convection Models for Significant Fluctuations in Seafloor Spreading.” Earth Planet. Sci. Lett. 383: 92-100.

[74] Boschman, L. M., and van Hinsbergen, D. J. J. 2016. "On the Enigmatic Birth of the Pacific Plate within the Panthalassa Ocean." Sci. Adv. 2 (7): e1600022.

[75] Larson, R. L., Fisher, A. T., Jarrard, R. D., and Becker, K. 1993. "Highly Permeable and Layered Jurassic Oceanic Crust in the Western Pacific." Earth Planet. Sci. Lett. 119: 71-83.

[76] Ito, G., and Clift, P. D. 1998. "Subsidence and Growth of Pacific Cretaceous Plateaus." Earth Planet. Sci. Lett. 161 (1): 85-100.

[77] Carlson, R. L., Christensen, N. I., and Moore, R. P. 1980. "Anomalous Crustal Structures in Ocean Basins: Continental Fragments and Oceanic Plateaus." Earth Planet. Sci. Lett. 51 (1): 171-80.

[78] Stein, M., and Ben-Avraham, Z. 2007. "9.07-Mechanisms of Continental Crust Growth A2-Schubert, Gerald." In Treatise on Geophysics, Amsterdam: Elsevier, pp. 171-95.

[79] Abbott, D., Burgess, L., Longhi, J., and Smith, W. H. F. 1994. “An Empirical Thermal History of the Earth's Upper Mantle." J. Geophys. Res. Solid Earth 99 (B7): 13835-50.

[80] Tejada, M. L. G., Suzuki, K., Hanyu, T., Mahoney, J. J., Ishikawa, A., Tatsumi, Y., et al. 2013. "Cryptic Lower Crustal Signature in the Source of the Ontong Java Plateau Revealed by Os and Hf isotopes." Earth Planet. Sci. Lett. 377-378: 84-96.

[81] Tharimena, S., Rychert, C. A., and Harmon, N. 2016. "Seismic Imaging of a Mid-Lithospheric Discontinuity beneath Ontong Java Plateau." Earth Planet. Sci. Lett. 450: 62-70.

[82] Richardson, W. P., Okal, E. A., and Van der Lee, S. 2000. "Rayleigh-Wave Tomography of the Ontong-Java Plateau." Phys. Earth Planet. Inter. 118 (1): 29-51.

[83] Ingle, S., and Coffin, M. F. 2004. "Impact Origin for the Greater Ontong Java Plateau?" Earth Planet. Sci. Lett. 218 (1-2): 123-34.

[84] Chandler, M. T., Wessel, P., Taylor, B., Seton, M., Kim, S.-S., and Hyeong, K. 2012. "Reconstructing Ontong Java Nui: Implications for Pacific Absolute Plate Motion, Hotspot Drift and True Polar Wander." Earth Planet. Sci. Lett. 331-332: 140-51.

[85] Ballmer, M. D., Ito, G., van Hunen, J., and Tackley, P. J. 2010. "Small-Scale Sublithospheric Convection Reconciles Geochemistry and Geochronology of
'Superplume' Volcanism in the Western and South Pacific." Earth Planet. Sci. Lett. 290 (1-2): 224-32.

[86] Bond, D. P., and Wignall, P. B. 2014. "Large Igneous Provinces and Mass Extinctions: An Update." Geol. Soc. Am. Spec. Pap. 505: 29-55.

[87] Van Thienen, P., Vlaar, N., and van den Berg, A. 2004. "Plate Tectonics on the Terrestrial Planets." Phys. Earth Planet. Inter. 142 (1-2): 61-74.

[88] Van Hunen, J., and Moyen, J.-F. 2012. "Archean Subduction: Fact or Fiction?" Annu. Rev. Earth Planet. Sci. 40 (1): 195-219.

[89] Herzberg, C., Condie, K., and Korenaga, J. 2010. "Thermal History of the Earth and Its Petrological Expression.” Earth Planet. Sci. Lett. 292 (1-2): 79-88.

[90] Jin, Y. G. 2000. "Pattern of Marine Mass Extinction Near the Permian-Triassic Boundary in South China." Science 289 (5478): 432-6.

[91] Shen, S. Z., Crowley, J. L., Wang, Y., Bowring, S. A., Erwin, D. H., Sadler, P. M., et al. 2011. "Calibrating the End-Permian Mass Extinction.” Science 334 (6061): 1367-72.

[92] Ward, P. D. 2000. "Altered River Morphology in South Africa Related to the Permian-Triassic Extinction." Science 289 (5485): 1740-3.

[93] Rampino, M. R., Prokoph, A., and Adler, A. 2000. "Tempo of the End-Permian Event: High-Resolution Cyclostratigraphy at the Permian-Triassic Boundary." Geology 28 (7): 643-6.

[94] Wang, K., Geldsetzer, H. H. J., and Krouse, H. R. 1994. "Permian-Triassic Extinction: Organic $\delta 13 \mathrm{C}$ Evidence from British Columbia, Canada.” Geology 22 (7): 580-4.

[95] Sun, Y., Joachimski, M. M., Wignall, P. B., Yan, C., Chen, Y., Jiang, H., et al. 2012. "Lethally Hot Temperatures during the Early Triassic Greenhouse." Science 338 (6105): 366-70.

[96] Berner, R. A. 2002. "Examination of Hypotheses for the Permo-Triassic Boundary Extinction by Carbon Cycle Modeling." Proc. Natl. Acad. Sci. 99 (7): 4172-7.

[97] Bambach, R. K., Knoll, A. H., and Wang, S. C. 2004. "Origination, Extinction, and Mass Depletions of Marine Diversity.” Paleobiology 30 (4): 522-42.

[98] Christensen, U. 1995. "Effects of Phase Transitions on Mantle Convection." Annu. Rev. Earth Planet. Sci. 23: 65-88.

[99] Machetel, P., and Weber, P. 1991. "Intermittent Layered Convection in a Model Mantle with an Endothermic Phase Change at $670 \mathrm{~km}$." Nature 350 (6313): 55-7.

[100] Pierce, K. L., and Morgan, L. A. 2009. "Is the Track of the Yellowstone Hotspot Driven by a Deep Mantle Plume?-Review of Volcanism, Faulting, and Uplift in Light of New Data." J. Volcanol. Geotherm. Res. 188 (1-3): 1-25. 
[101] Schmandt, B., Dueker, K., Humphreys, E., and Hansen, S. 2012. "Hot Mantle Upwelling across the 660 beneath Yellowstone." Earth Planet. Sci. Lett. 331-332: 224-36.

[102] Wolfe, C. J., Solomon, S. C., Laske, G., Collins, J. A., Detrick, R. S., Orcutt, J. A., et al. 2011. "Mantle P-Wave Velocity Structure beneath the Hawaiian Hotspot." Earth Planet. Sci. Lett. 303 (3-4): 267-80.

[103] Duncan, R. A. 1982. "A Captured Island Chain in the Coast Range of Oregon and Washington." Journal of Geophysical Research Solid Earth 87 (B13): 10827-37.

[104] Madsen, J. K., Thorkelson, D. J., Friedman, R. M., and Marshall, D. D. 2006. "Cenozoic to Recent plate Configurations in the Pacific Basin: Ridge Subduction and Slab Window Magmatism in Western North AMERICA.” Geosphere 2 (1): 11-34.

[105] Draper, D. S. 1991. "Late Cenozoic Bimodal Magmatism in the Northern Basin and Range Province of Southeastern Oregon.” J. Volcanol. Geotherm. Res. 47 (3): 299-328.

[106] Camp, V. E. 2013. "Origin of Columbia River Basalt: Passive Rise of Shallow Mantle, or Active Upwelling of a Deep-Mantle Plume?" In Geological Society of America Special Papers, vol. 497, Geological Society of America, pp. 181-99.

[107] Hofmann, C., Feraud, G., and Courtillot, V. 2000. " $40 \mathrm{Ar} / 39 \mathrm{Ar}$ Dating of Mineral Separates and Whole
Rocks from the Western Ghats Lava Pile: Further Constraints on Duration and Age of the Deccan Traps." Earth Planet. Sci. Lett. 180: 13-27.

[108] Richards, M. A., Alvarez, W., Self, S., Karlstrom, L., Renne, P. R., Manga, M., et al. 2015. "Triggering of the Largest Deccan Eruptions by the Chicxulub Impact." Geol. Soc. Am. Bull. 127 (11-12): 1507-20.

[109] Renne, P. R., Sprain, C. J., Richards, M. A., Self, S., Vanderkluysen, L., and Pande, K. 2015. "State Shift in Deccan Volcanism at the Cretaceous-Paleogene Boundary, Possibly Induced by Impact." Science 350 (6256): 76-8.

[110] Kious, W. J., and Tilling, R. I. 1994. This Dynamic Earth: The Story of Plate Tectonics. Washington, D. C: US Geological Survey: For sale by the US G.P.O.

[111] Poreda, R. J., and Becker, L. 2003. "Fullerenes and Interplanetary Dust at the Permian-Triassic Boundary." Astrobiology 3 (1): 75-90.

[112] Becker, L. 2002. "Impact Event at the Permian-Triassic Boundary: Evidence from Extraterrestrial Noble Gases in Fullerenes." Science 291 (5508): 1530-3.

[113] Kaiho, K., Yoshimichi, K., Takanori, N., Yasunori, M., Hodaka, K., Kazue, T., et al. 2001. "End-Permian Catastrophe by a Bolide Impact: Evidence of a Gigantic Release of Sulfur from the Mantle." Geology 29 (9): 815-8. 